This is the accepted version of the following article: Pilcher, Robyn and Gilchrist, David and Singh, Harjinder and Singh, Inderpal. 2013. The interface between internal and external audit in the Australian Public Sector. Australian Accounting Review. 23 (4): pp. 330-340. which has been published in final form at http://doi.org/10.1111/auar.12032

\title{
The Interface between Internal and External Audit in the Australian Public Sector
}

\author{
Associate Professor Robyn Pilcher \\ Professor David Gilchrist \\ Dr Harjinder Singh \\ Associate Professor Inderpal Singh
}

\begin{abstract}
This project was designed to answer the research question 'Using reliance as the pivotal consideration, what factors determine the efficient and effective interrelationship between internal and external audit?', within the context of the Australian public sector. A qualitative approach, framed within agency theory, was adopted using a case study and structured interviews. Findings included factors supporting prior literature as well as some unique to the research described here. As a result, this paper makes a contribution to literature examining public sector internal and external audit interrelationships as well as literature on police audit and performance. It also has practical implications for both the case study site and similar organisations throughout the world.
\end{abstract}

\section{Corresponding Author}

Associate Professor Robyn Pilcher

Curtin University

School of Accounting

GPO Box U1987

Perth WA 6845

r.pilcher@curtin.edu.au

Ph: +61 892662879

Key words: internal audit; external audit; communication; case study; public sector; agency theory

Research Classification: M42 - Auditing

\section{Acknowledgements}

Dr Robyn Pilcher is an Associate Professor in the School of Accounting at Curtin University. She is an FCPA and FIPA; David Gilchrist is a Professor in the School of Accounting at Curtin University. He is an FCA and FAICD; Dr Harjinder Singh is a Senior Lecturer in the School of Accounting at Curtin University. Dr Inderpal Singh is an Associate Professor in the Department of Accounting and Finance at the University of Western Australia.

The authors would like to acknowledge the anonymous reviewers of the Australian Accounting Review as well as the reviewers and participants of the Accounting and Finance 
Association of Australia and New Zealand (AFAANZ) July 2011 conference. They also gratefully acknowledge funding from AFAANZ through an Academic Research Grant.

\section{The Interface between Internal and External Audit in the Australian} Public Sector

\section{Introduction and Background}

Prior research in the private sector has considered the relationship between internal and external audit (eg, Edge and Farley 1991; Krishnamoorthy, 2002; Munro and Stewart, 2011). Nevertheless, due primarily to the relatively recent formal introduction of internal audit into public sector agencies across jurisdictions in Australia, little research exists examining the relationship between external and internal audit in that sector. This study begins to bridge the gap in the extant literature by examining the extent of reliance placed by the external auditor on the work of the internal audit function within one of Australia's largest public sector agencies. Insights are also provided into the factors which determine this reliance given the myriad externalities influencing the process. To ensure confidentiality the actual agency - a police force - and state will remain anonymous. ${ }^{1}$ ABC Police was selected for the case study for various reasons. Firstly, the organisation has the largest internal audit function of all state government agencies; secondly, it has received accolades for its financial reporting; thirdly, whereas some agencies outsource their internal audit function that was not the case here; fourthly, it was expected that if communication channels were flawed then this could very well be the case across all agencies; and, finally, it provides fertile ground for future research using agency theory in the context of multiple principal/agent relationships. Recent changes to the auditing standards, specifically the Auditing and Assurance Standards Board (AuASB)'s Auditing Standard ASA 610 Using the Work of Internal Auditors, and how these changes are likely to impact the decision to rely upon the work completed by internal audit, are also examined. 
A number of regulatory reforms have resulted in an increasing emphasis on the role of internal audit as an important corporate governance mechanism in both the private and public sectors (Goodwin, 2004). While there are crucial differences between internal auditing in the two sectors (Coupland, 1993), public sector reforms have sought to reduce these differences, especially in relation to governance (Barrett, 2002a, b). This has been achieved largely by the public sector adopting governance and management frameworks with underpinning origins in the private sector. Such efforts suggest that reform efforts may result in models being made to fit the public sector rather than developing appropriate sector specific models.

As internal audit becomes more widely implemented in the Australian public sector, the potential for external auditors relying on the work of the internal auditors increases (Ward and Robertson, 1980). The extent of such reliance will, however, inter alia, depend upon the ability and willingness of external and internal auditors to communicate effectively with the aim of increasing their co-ordination efforts (Haron et al., 2004; Brody et al., 1998). Prior research in the private sector concluded that three factors - 'competence, objectivity and work performed' - are used by external auditors to determine whether or not to rely on internal auditors' work (Haron et al. 2004: 1151). An important contribution of this study is the investigation of these private sector concepts within a public sector setting. Given that public funds are used by state government agencies to provide services, efficiencies are an important consideration within the public sector.

Internal and external audit are clearly significant monitoring mechanisms for ensuring efficacy and efficiency in public sector expenditure in their own right. However, appropriate reliance by external audit on internal audit can also achieve significant efficiencies including: managing myriad stakeholders; communicating planned objectives; ensuring timely audits are conducted; and avoiding duplication (McPhee, 2005). Although outside the scope of this 
paper, the audit committee (as the third point of the audit trinity) also plays an important role in the interrelationship between internal and external audit. Zammit and Baldacchino (2012) found that better communication and more readiness to consult were two factors needing improvement when they examined the relationship between internal and external audit functions in Malta's public sector. Zammit and Baldacchino (2012) claimed this finding was generalisable across other countries, both developed and developing.

The importance of communication between the external and internal auditors is well documented in the literature (including in ASA 610 updated in October 2009). It has been argued that communication barriers between the two can significantly impair the efficiency and effectiveness of an audit (Brody et al., 1998). Whittington (1989: 125) noted that whilst effective communication minimises the overlap of audit efforts, it requires 'joint planning and co-ordination, open lines of communication and a consideration of various aspects of human relations'.

The following section provides a brief review of the literature and an introduction to the Australian public sector. This is followed by the theoretical framework and the research design. The penultimate section articulates and discusses the results with the final section concluding the article.

\section{Literature Review}

Internal auditing is designed to support organisations in achieving their objectives (Internal Auditors in Australia (IIA, www.iia.org.au)) and has evolved from risk management, control and governance processes (Gay and Simnett, 2007), to an assurance and consulting service concerning risk exposures and control strategies (Leung et al., 2007). 
There has been extensive research on the importance of an internal control function as part of an effective corporate governance structure. Prior internal audit research has evaluated: objectivity issues (Church and Schneider, 1992; Brody and Lowe, 2000; Stewart and Sabramaniam, 2010); the interaction between internal and external audit (Stein et al., 1994; Brody et al., 1998; Felix, Gramling, and Maletta, 2001; Mihret and Admassu, 2011; Prawitt et al., 2011); the trend to outsource internal audit functions (Caplan and Kirschenheiter, 2000; Dickins and O'Reilly, 2009; Majdalawieh and Alkafaji, 2012); and the relationship between internal audit and the audit committee (Leung, et al., 2004; Christopher, et al., 2009; Davies, 2009; Sarens et al., 2009).

More recently, research pertaining to the role of internal audit has broadened to encompass risk management and corporate governance (Brody and Lowe, 2000; Carey et al., 2006; Leung et al., 2011). Internal auditors can add value by providing assurance that organisational risks are properly identified and managed (Leithhead, 1999; Walker et al., 2003). In Australia, legislation establishes internal and external audit arrangements (Goodwin, 2004). In this case, the relevant state legislation and regulations apply to all government entities and requires them to establish an internal audit function.

The contemporary corporate governance setting has led to a greater focus on the relationship between internal and external auditors (Gramling et al., 2004). The work performed by internal auditors may affect external audit efficiency as it can be a factor in determining the level of work required (Schneider, 1985). Inter alia, ASA 610 provides guidance to the external auditor in this regard.

Communication helps ensure the placing of an appropriate level of reliance on the work of the internal auditors (eg, ASA 610, para 4; Lempe and Sutton, 1994; Brody et al., 1998; Felix et al., 2001). Within the police itself, prior literature (although relatively scarce) supports the 
need for greater communication within and between relevant stakeholders (Collier et al., 2004). Aligned with co-ordination and communication is the desire to reduce the total audit fees charged. Any efficiencies (and inefficiencies) gained can be reflected in the audit fee (Lempe and Sutton, 1994; Brody et al., 1998; Felix et al. 2001). In the Australian public sector, the issues of efficiency and the quantum of audit fees are considerably more complex given the interests of the taxpayer. In relation to this state, efficiency is important because fees are determined via a cost recovery model. Hence rewards for efficiency flowing from amongst other things - internal and external audit co-ordination are prized by audited entities.

However, audit processes are also informed by the relationships surrounding the organisation being audited. In the case of the public sector these relationships are very complex. This means that the relationship between internal and external audit is critical in achieving an efficient and effective audit outcome. As such, a major difference between the public and private sectors in relation to audit, is the complexity resulting from a multiplicity of audiences (e.g. the parliament, the ministry, the public sector agencies and the public itself) each with very different expectations. For instance, Rainey (1997: 38) argued that 'public agencies are born of and live by satisfying interests that are sufficiently influential to maintain the agencies' political legitimacy and the resources that come from it'. The Minister will always be more concerned with what the voting public thinks of him/her whereas taxpayers just want to see effective services being provided. As a result, the objectives of each function (internal and external audit) may be different and the differences are likely to be enhanced by the interests of agents. The findings from this research will inform and influence literature in this area by answering the research question posed in the abstract, being: 'Using reliance as the pivotal consideration, what factors determine the efficient and effective interrelationship between internal and external audit?' 


\section{Theoretical Framework}

Research in auditing has traditionally been carried out under the framework of agency theory (Watts and Zimmerman, 1986). Literature is either scant regarding theoretical frameworks for auditing in the public sector or it implicitly relies on research pertaining to the private sector. Since auditing is a monitoring mechanism on the veracity of financial reporting, agency theory is an appropriate starting point from which to examine the relationship between external and internal audit in the public sector.

Much of agency theory focuses on notions of accountability with Mayston (1993) arguing that the principal-agent model and accountability holds in the public sector. However, public sector accountability is 'not a simple one-to-one relationship between a principal and agent' (Mayston, 1993: 77) but is a relationship between a number of different groups whose economic and political interests overlap. Conducting effective and efficient audits becomes more critical to accountability given the multiple principal-agent relationships in the public sector (Cheng, 1994; Morrell, 2006). It is argued that, for the purposes of the research reported here, there are direct and indirect principals and agents in a democratic state. Such clarification is important as it allows for a more direct assessment of the findings. Singleton et al. (2003) identifies that members of the government (that is, ministers or the cabinet) will be punished by perceived inefficiencies in the public sector. As such, a direct principal agent relationship can be said to exist between the elected government and the public sector which is charged with the implementation of the government's policy. Hughes (2003: 236) considers that '[t]here is a fundamental requirement in a democratic system for accountability from the administration to the political leadership'. While the community is important, the government stands or falls based, in part, on its administrative record and so has a more direct and significant interest in reducing agency costs to it. This is a highly politicised environment. 
To reduce these costs, governments (principals) demand and the public sector (agents) supply monitoring of their activities (Jensen and Meckling, 1976). A contribution of this paper, then, is to confirm the role of agency theory in explaining the need for, and outcomes associated with, audit in the public sector and indeed to confirm the role of the external and internal auditors in enhancing public accountability notwithstanding the highly politicised environment.

The political dimension is important here as the police agency considered in this case is a high profile one that is constantly under the scrutiny of commentators and the public at large. The government members of parliament are likely to be punished when the police do not perform well - or are perceived not to have performed well - and so the Commissioner and senior staff within the agency come under political pressure to perform. With the external auditor reporting to the parliament and the internal auditor to the Commissioner of Police (the Chief Executive), the ability of the external auditor to rely on internal audit may be reduced markedly as their audiences’ expectations are potentially quite divergent.

\section{Research Design}

\section{Research Method}

A qualitative approach was adopted for this research using a single case study (as described shortly). In general terms, since the late 1980s, case study research has been seen as a response to the call to develop a greater understanding of how management accounting actually functions in organisations and society (eg Hopwood, 1979 and 1983; Jensen, 1983; Kaplan, 1983, 1986; Yin, 1994; Gill, 2009). In this research, use of an in-depth case study allowed the researchers to gain an understanding of the relationship between internal audit (ABC Police Management Audit Unit (MAU)) and the external auditor (Office of the Auditor-General (OAG)) (Kennerley et al. 2003). 'How' questions (eg How much do you 
perceive the OAG relies upon the internal audit work?) were determined to be important in generalising to the theoretical proposition establishing the relationship between multiple agents and principals in the public sector (Yin, 1994). Such a relationship is a complex one with accountability driving the requirement for efficiencies between the two. Focused interviews consisting of both open- and close-ended questions were conducted with questions based on the experience of the main author, prior literature (in particular Goodwin, 2003; Gramling and Hermanson, 2009; Martinov-Bennie and Soh, 2009) and discussions with the Assistant Director of the ABC Police MAU. In regards to questions for the OAG, these were designed from responses received from the Police MAU interviewees and, again, prior literature.

Initially document analysis was undertaken. This analysis was one component of a dual method approach designed to obtain a full understanding of the ABC Police MAU (see for example, Miller and O'Leary, 1998; Lapsley et al., 2010). Then, structured interviews of nine staff employed in internal audit activities within the MAU - consisting of both sworn police officers and civilian staff - were undertaken. ${ }^{2}$ Hence, all levels of staff from the most junior internal auditor through to the manager of the MAU, were interviewed. These interviews were conducted during 2010. This was a typical year for ABC Police with no more than normal media attention being paid to the organisation. Prior to the formal interview process, ethical clearance was provided by all participants. To enable the researchers to have more of an understanding of the MAU staff, short questionnaires were sent to each member prior to the day of the interviews. These questionnaires sought information on issues such as qualifications, time as an auditor, and time spent with ABC Police (see Appendix I).

Each interview itself took approximately one and a half hours. The interview questions were designed to gain as much information as possible about the assurance audit process. It was 
essential to consider the perceptions of each of the interviewees who represented different levels of the audit process (see Appendix II). Similar to other case study / interview research (see for example Qian et al. 2011), all interviewees were supplied with a consent form which they were asked to sign on the day of the interviews, and a participant information sheet explaining the research. If the interviewees agreed (which all did), then interviews were recorded, with a research assistant typing notes directly into a laptop and physical notes being taken by the researcher. These notes and recordings were subsequently transcribed. The documented transcriptions were then sent back to the relevant participants for confirmation.

In regards to the external auditor, seven staff involved in the police audit team from the OAG were also interviewed. As above, the interviewees included all levels of auditors involved in the audit team. Again consent forms and participant information sheets were supplied; interviews recorded and notes taken which were subsequently transcribed and checked by the interviewees. Personal information was not obtained from the OAG staff as the OAG was the only external auditor and all staff were required to follow a set remit. The interviews were then analysed using thematic analysis with coding done manually (see, for example, Creswell, 2007). Findings from the interviews were subsequently aligned with the document analysis to aide in answering the research question posed at the beginning of this paper.

\section{Case Study}

ABC Police is responsible for policing a geographically large jurisdiction. This is an important issue as, politically, service delivery requirements and social outcomes are difficult to achieve in many geographically isolated communities where there are very high risk populations. Ministers are required to ensure the government's 'politically acceptable' outcomes (including service delivery) are achieved at the lowest cost possible (English and Guthrie, 2002). When disparities between metropolitan and regional service delivery are 
identified or when poor or inappropriate performance is identified, significant political consequences usually follow. Given the discussion above emphasising the political aspect, an example here would be when police stations are closed in lower populated areas, the public show their displeasure by the way they vote. Hence, ministers or local state representatives can find themselves being exposed negatively in the media and without a job at the next election (see, for example, Rainey, 1997; Redmayne et al., 2010). This reality would suggest that, while quantitatively these regions may be immaterial, there is a significant qualitative materiality to public sector service delivery within them.

The agency has an organisational structure comprising three regions, 14 districts, 163 police stations and approximately 5,000 police officers. As an integral part of ABC Police, the MAU is a small multi-disciplinary team that has been formed to independently appraise the activities, operations and systems of the agency. In line with research considering the role of internal audit in an organisation (see for example, Arena and Azzone, 2009) the MAU provides an internal audit function intended to add value to the management of the agency by reporting findings and making recommendations aimed at reducing any prospective incidence of unintended outcomes and at increasing efficiency. It has a legislated mandate to examine all parts of the agency and plays an important role in providing independent advice to management in support of the agency's efficient and effective operation.

The MAU undertakes key internal audit functions including assurance audits and reviews of controls; comprehensive topic audits; coordination of the Business Area Management Review $(\mathrm{BAMR})^{3}$ program; and other associated activities such as internet and email monitoring, professional consultation and management initiated reviews. Of note, with ABC Police covering a large geographical area, it is impractical for the MAU to audit all districts within its jurisdiction. Of course, as discussed above, this reality has ramifications possibly resulting 
in adverse political and functional outcomes with the result of reduced political support for the government. BAMR involves senior police officers auditing various aspects of the recordkeeping and operation of police stations on a regular basis such that all aspects are audited at least once during a twelve month period. The BAMR program plays a significant role in achieving the MAU's goals by identifying and addressing weaknesses particularly in each business area's procedures, systems and management practices. Internal governance processes are reviewed to ensure continued compliance with relevant statutory requirements and agency policies as well as the safeguarding of resources within the agency.

In relation to this case, the Auditor General is supported by the OAG and, by legislation, is an independent officer of the parliament. The State Auditor-General audits the ABC Police.

\section{Findings and Discussion}

In regards to this research, information was obtained about the process and perceived efficiencies around the internal and external audit. Three major findings were evident from the study relating to reliance, planning and resource allocation. Implicit in each of these findings was the issue of communication.

\section{Reliance}

The first finding related to the internal audit's perception of the extent of reliance placed on their work by the external audit team. Prior research in public sector internal auditing reports that more than $85 \%$ of internal audit functions coordinate the areas of audit coverage with the external auditor; two thirds coordinate their work schedule; and access by external auditors to internal audit work papers and reports does not present a problem (Goodwin, 2004). These results appear consistent with findings here. Unfortunately the internal audit staff assumed the external auditors were relying on their work based on the number of reports requested (as per ASA 610). However, according to Funnell (2003), what is actually in these reports may 
not enhance accountability if it isn't relevant to the particular stakeholder. In this case, and it will be evident below, Funnell (2003) was correct. Within the MAU itself, confidence was displayed with all respondents claiming that the external auditors placed between $80-100 \%$ reliance on their work. Comments included:

They would rely a lot on my team's efforts, at least $80-100 \%$. (MAU) ${ }^{4}$

The external effort relies so much on what the internal audit does because they have very limited hours that they can devote to auditing an agency this size. Consequently they need to rely very heavily on the internal audit function. (MAU)

On the other hand, the external auditors had an entirely different viewpoint. BAMR audit results were relied upon while MAU audit results were not - notwithstanding the reported comments from the external auditor that BAMR has 'issues' (discussed later in this section). According to respondents from the external audit team, a significant reason that BAMR results were relied upon was that it was too costly to send an external audit team to various parts of regional parts of the State. However, external audit was, nevertheless, careful to gain an understanding of the work done. As to other controls, it was found that a maximum of $15 \%$ of internal audit work was relied upon.

Not more than $15 \%$ - and that is BAMR. (OAG)

I would say that we probably don't rely a lot on internal audit mainly because of the way our methodology is at the time. (OAG)

Reasons for this discrepancy included timing of cycles, duration examined and scope of the audits.

Historically as it turns out the main impediment for our reliance has been the period of reliance. It's just usually the period is too small to rely on efficiently. (OAG)

Questions need to be asked as to why this is a recurring problem. The ABC Police have received formal recognition for their reporting, so their competence is not in question. In their 
response to questions about reliance, some interviewees claimed that the external auditors did not communicate their degree of reliance to the MAU and so the perceptions of both internal and external audit have remained unchanged over a number of periods. A recognition that barriers to communication exist between internal and external auditors is critical before improvements in communication can be made (Brody et al., 1998). A lack of communication can also be an indication of a lack of trust which, in turn, impacts on reliance. For example, external auditors are not taking full advantage of internal audit work completed. Reasons for this lack of reliance are not communicated sufficiently. It could even be intimated that some of the internal audit team work in silos:

I literally come here and do my work and that's about it ... I really don't get involved (MAU).

\section{Planning}

The second finding related to the planning of internal audits. It was evident that risk management is now considered explicitly in regards to planned and requested audits across the Agency.

It has sharpened our resolve to better identify and allocate our projects or our audit work according to risk (MAU).

We have now got a recognised framework, a risk management framework that applies right across our organisation that I can use based on what that [the risk management framework] generates (MAU).

It acts as a basis to direct our audit resources. Before we did not have that - it was ad hoc and reactive (MAU).

The twelve Attributes of Effectiveness is an auditing framework [that]... may be considered dated by today's standards [but which]... provides a sound basis to develop internal audit plans (MAU).

Initially risk management was an audit thing, a control thing ... but it is now more of a planning thing (MAU). 
Of course, the above comments do not deal with the propensity for the most senior staff in the organisation to require ad-hoc and unplanned work to be prioritised above planned work. The MAU considered that their annual audit activities included incorporating a 'planned' component whilst at the same time responding to demands from across the agency particularly from the Commissioner - to conduct ad-hoc audits at various times during the year. Although, from the MAU's viewpoint, the external auditors see the internal audit plan prior to it going to the Audit and Risk Management Committee, very little external input is received. This is an issue in relation to audit efficiency and the extent to which external audit seeks to inform internal audit with a view to ensuring work done by internal audit supplements that of external audit. The external auditors on the other hand claimed they provided input as to the areas they would like the MAU to focus on. As mentioned above, this lack of communication results in the external audit's perception that the MAU won't change their planning strategy. Where in the process this breakdown in communication occurs is something to be established by the parties involved. Notwithstanding the MAU's considered opinion that the external auditors provide minimal input, the following comment was made by a member of the OAG's team:

Part of our planning is obviously to consider the work with internal audit. So there we have a meeting with the Assistant Director in the area and one or two of the other guys. We meet with him to see what type of reliance we can place on the work based on the audit planning. Before the audit plan goes to the audit committee we provide input as to what areas we would like them to focus on (OAG).

The external auditor meets with the MAU on a regular basis throughout the year. The identified lack of communication appears less a result of a lack of opportunity than a lack of a planned approach to meetings or the fact that more pressing issues may be imposed by management on the MAU. 
Agency costs are likely to increase when ad-hoc internal audit work takes precedence over planned work and when the planned internal audit work carried out is not relied upon by the external auditor. Ad-hoc requirements are in many cases evidence of the very political nature of the direct principal / direct agent relationship discussed earlier. This outcome might be averted by the application of additional resources toward the achievement of the internal audit plan, allowing for a resource allocation to take on ad-hoc work as it is identified. However, this has costs associated with it and may mean that, in time, more ad-hoc responsive work is undertaken rather than planned audit work.

\section{A Further Finding - Resource Issues}

The last finding was concerned with how an internal audit function operating in a jurisdiction which is spread over a vast geographical area, can effectively and efficiently audit all the locations and operations within the agency. While resource allocation in these areas may be relatively immaterial, as described above, many locations service vulnerable communities and poor performance potentially excites significant political repercussions resulting in political costs to the government (direct principals). As a control self-assessment tool, theoretically it was considered by ABC Police that BAMR had the potential to be an excellent resource. However, there were still significant problems associated with the resourcing of the function using uniformed officers in regional locations. In these areas in particular, where human resources were limited, questions were raised by the external auditor as to the effectiveness of the controls and the ability of the staff to perform these selfassessment audits.

The issue is because the country towns are not interested in the compliance - they are not trained to do so and their priority is not there. Also the staffing level ... there are very few people at some stations [and so] they don't have time (OAG). 
In other words, it was recognised by the OAG that BAMR may have resourcing issues. The competency of the staff to conduct effective internal audits was questioned by the external auditor. This lack of competence is likely to lead to a lack of reliance which was also raised by the MAU. Finally, the MAU identified the practice of using sworn officers to conduct audits as problematic:

Officers on the ground think it is something onerous and it has been pushed down on them. Whereas if you said to them, right you have just locked someone up for stealing, you have to do this, that and the other. They understand that very well. I think there has to be more education. The supervisors need to get this right. (MAU)

Under these circumstances, questions are raised as to the extent to which external audit could

realistically rely on such results. Yet, findings revealed that the majority of OAG staff interviewed claimed they relied $100 \%$ on BAMR. Additionally, the finding increases the importance of the overall finding that communication is not effective between the external and internal audit teams. Although both the external auditor and MAU manager recognise there are serious issues, a lack of communication results in no effective solution being advanced.

\section{Implications and Conclusions}

The initial objectives of this research were to determine: (1) the extent of reliance placed by the external auditor on the work of the internal audit function; and (2) the factors impacting that reliance. Findings included in the previous section highlighted a lack of reliance on the work of the internal audit function in a large Australian public sector agency. Some of the relevant issues or factors included: (1) resource issues such as limited hours; limited human resources; and the cost associated with auditing regional areas of a large state; and (2) confusion in what each function expected of the other (that is, problems in the planning stage). A perceived lack of competence of some staff conducting the internal audit, in turn, implied a lack of trust. The decision by the external auditors as to what extent they rely on the 
work of the ABC Police internal audit function has clear ramifications for the efficiency and effectiveness of the audit and how this process enhances public accountability (eg Felix et al. 1998). Underlying all these findings, was the critical reality that each party perceived the level of successful communication differently. Communication - or a lack thereof - was implicit in each of the findings discussed in Section 5 - reliance, planning and resources. However, neither party seemed to have identified it as an issue.

Hence, one major implication of this research is the need to improve communication channels between the external and internal auditors. This could be generalizable across other agencies as well as across state jurisdictions (particularly given this supports prior literature in other countries, for example, Collier et al., 2004). Internal audit functions in other high profile agencies are also likely to suffer from ad-hoc demands from senior management resulting in higher agency costs to the extent that these ad-hoc assignments render the planned internal audit work unreliable by the external auditors. From the OAG's perspective, if more efficiencies could be achieved, then less audit work would need to be outsourced, thus reducing overall costs required to be recovered. From the agency's perspective, with all public sector agencies being told regularly they need to reduce their expenditure this is one possible area which could contribute to the reduction.

Of course, communication barriers are also likely to have a negative impact on the efficiency of the external audit. With the changes to ASA 610 focusing on communication between the external and internal auditors, this presents an opportunity for improving the coordination between the two parties to contribute to the efficiency and effectiveness of the external audit. Opportunities are likely also to arise to provide training and professional development in the area of communication and coordination between the external auditor and internal auditors. Effective coordination should be achieved in the planning stage and hence the OAG might be 
best placed to prioritise this training and to lead it in an effort to effectively re-establish effective communication. As the changes to ASA 610 take effect, public sector agencies (via the audit committees) together with the OAG could develop best practice operational procedures around communication between auditors. This, in turn, could lead to increased efficiencies and potentially lower audit fees in the medium term. At the least, it could lead to the maintenance of real costs to auditees over the medium term. Improved communications between external and internal auditors is likely to result in MAU being able to focus their planned audits while allowing for ad-hoc requests thereby achieving their audit objectives and reducing agency costs.

As discussed above, Mayston (1993) recognised that instead of there just being a single principal / agent relationship in relation to public sector accountability, there are a number of different groups whose economic and political interests overlap. Conducting effective and efficient audits becomes more critical to accountability given the multiple principal-agent relationships in the public sector. In the police there are multiple relationships that can influence the effectiveness of the internal audit process, the line of communication and thus the reliance placed on the results. The most direct relationship is that of the Minister of Police representing the principal and the Commissioner of Police representing the agent. However, within the police itself there is also an indirect principal/agent interrelationship between the Commissioner as the Chair of the Risk Management and Audit Committee and the manager of the internal audit function. The external auditors are also agents of the Minister and hence efficient and effective communication, reliance and overall decision-useful information is imperative for true accountability within the public sector.

Future research will extend this study to include the ABC Police Audit Committee as well as examine more closely the effectiveness of BAMR. It is then intended to expand the research 
to include all state government agencies. The ABC Police has provided insights into why there are occasions where external audit is unable to place reliance on the work of the internal auditors given insurmountable barriers, such as geographic size of the operational area and risk being interpreted more from an operational rather than a financial perspective. Further investigation could also determine if this is the case throughout Australia and in countries such as New Zealand and the United Kingdom. It also provides an opportunity to investigate audit in this unique area - that of police - across Australia and the world.

\section{Notes}

1. To ensure confidentiality the state referred to in Australia will just be known as ABC State and the police force ABC Police. Further, legislation will not be directly referenced in order to preserve this confidentiality.

2. A total of 12 staff are employed in MAU, however, one was on long-term sick leave and the other two chose not to participate. The researchers were requested not to include personal information here so as not to identify any particular staff member.

3. BAMR: The Police Service operates an internal audit system known as 'Business Area Management Review' (BAMR). In short, BAMR involves senior police officers auditing various aspects of the record-keeping and operations of police stations on a regular basis so that all aspects are audited at least once during a twelve month period.

4. Quotes are only identified as coming from the MAU or OAG. No personal identifiers are included. 


\section{References}

Arena, M. and Azzone, G. 2009, 'Identifying Organizational Drivers of Internal Audit Effectiveness', International Journal of Auditing, 13, 1: 43-60.

Auditing Standard ASA 610 2009, Considering the Work of Internal Audit, Australian Government Auditing and Assurance Standards Board, October.

Barrett, Pat 2002a, 'Achieving Better Practice Corporate Governance in the Public Sector', Speech at the International Quality and Productivity Centre Seminar, June 26.

Barrett, Pat 2002b 'Expectation and Perception of Better Practice: Corporate Governance in the Public Sector from an Audit Perspective', Speech at CPA Australia's Government Business Symposium, Melbourne, September 20.

Brody, R.G., Golen, S.P. and Reckers, P.M.J. 1998, 'An Empirical Investigation of the Interface between Internal and External Auditors', Accounting and Business Research, 28, 3: 160-171.

Brody, R. G. and Lowe, D. J. 2000, 'The new role of the internal auditor: Implications for internal auditor objectivity', International Journal of Auditing, 4, 2: 169-176.

Caplan, D. H. and Kirschenheiter, M. 2000, 'Outsourcing and audit risk for internal audit services', Contemporary Accounting Research, 17, 3: 387-428.

Carey, P., N. Subramaniam and K.C.W. Ching. 2006, 'Internal audit outsourcing in Australia', Accounting and Finance, 46: 11-30.

Cheng, R.H. 1994, 'A Politico-Economic Model of Government Accounting Policy Choice', Research in Governmental and Nonprofit Accounting, 8: 39-68.

Church, B. K. and Schneider, A. 1992, 'Internal auditor involvement in internal control system design: Is objectivity impaired?' Journal of Applied Business Research, 8, 4: 15-24.

Christopher, J., Sarens, G. and Leung, P. 2009, 'A critical analysis of the independence of the internal audit function: evidence from Australia', Accounting, Auditing and Accountability Journal, 22, 2: 200-20.

Collier, P., Edwards, J. and Shaw, D. 2004, 'Communicating Knowledge about Police Performance', International Journal of Productivity and Performance Management, 53, 5: 458-467.

Coupland, D. 1993, 'The Internal Auditor's Role in Public Service Orientation', Managerial Auditing Journal, 8, 1: 3-13.

Creswell, J.W. 2007, Qualitative Inquiry and Research Design: Choosing Among Five Approaches, SAGE Publications Inc, California. 
Davies, M. (2009), 'Effective working relationships between audit committees and internal audit - the cornerstone of corporate governance in local authorities, a Welsh perspective', Journal of Managerial Governance, 13, 1/2: 41-73.

Dickins, D. and O’Reilly, D. 2009, 'The qualifications and independence of internal auditors', Internal Auditing, 24, 3: 14-21.

Edge, W.R. and Farley, A.A. 1991, 'External Auditor Evaluation of the Internal Audit Function', Accounting and Finance, 31, 1: 69:83.

English, L. and Guthrie, J. 2002, 'Learning from International Public Management Reform Experience for Management Control Systems', A Paper Submitted for the European Accounting Association Conference, Denmark, April 25-27.

Felix, W.L., Gramling, A.A. and Maletta, M.J. 1998, Coordinating Total Audit Coverage: The Relationship Between Internal and External Auditors. The Institute of Internal Auditors Research Foundation.

Felix, W. L., Gramling, A. A., and Maletta, M. J. 2001, 'The contribution of internal audit as a determinant of external audit fees and factors influencing this contribution', Journal of Accounting Research, 39, 3: 513-534.

Funnell, W. 2003, 'Enduring Fundamentals: Constitutional Accountability and AuditorsGeneral in the Reluctant State', Critical Perspectives on Accounting, 14, 1-2: 107-132.

Gay, G. and Simnett, R. 2007, Auditing and Assurance Services in Australia, 3rd ed., McGraw Hill Irwin: North Ryde, Australia.

Gill, M. 2009, Accountants' Truth: Knowledge and Ethics in the Financial World, Oxford University Press, Oxford.

Goodwin, J. 2003, 'The Relationship Between the Audit Committee and the Internal Audit Function: Evidence from Australia and New Zealand', International Journal of Auditing, 7: 263-278.

Goodwin, J. 2004, 'A comparison of internal audit in the private and public sectors', Managerial Auditing Journal, 19, 5: 640 - 650

Gramling, A. and Hermanson, D.R. 2009, 'Internal Audit Quality: Would we know it if we saw it?', Internal Auditing, 24, 1: 36-39.

Gramling, A., Maletta, M., Schneider, A. and Church, B. 2004, 'The role of the internal audit function in corporate governance: a synthesis of the extant internal auditing literature and directions for future research', Journal of Accounting Literature, 23: 194-244.

Haron, H., Chambers, A., Ramsi, R. and Ishak, I. 2004, 'The reliance of external auditors on internal auditors', Managerial Auditing Journal, 19, 8/9: 1148-1159.

Hopwood, A.G. 1979, 'Editorial', Accounting, Organizations and Society, 4, 3: 145-147. 
Hopwood, A.G. 1983, 'On Trying to Study Accounting in the Contexts in Which it Operates', Accounting, Organizations and Society, 8, 2/3: 287-305.

Hughes, O., 2003, Public Management and Administration: An Introduction, $3^{\text {rd }}$ ed., Palgrave Macmillan, New York.

Internal Auditors in Australia (IIA), www.iia.org.au (accessed 12 September 2012).

Jensen, M.C. 1983, 'Organization Theory and Methodology', Accounting Review, 58, 2: 319339.

Jensen, M.C. and Meckling, W.H. 1976, 'Theory of the Firm: Managerial Behavior, Agency Costs and Ownership Structure', Journal of Financial Economics, 3, 4: 305-360.

Kaplan, R. S. 1983, 'Measuring Manufacturing Performance: A New Challenge for Managerial Accounting Research', Accounting Review, 58, 4: 686-705.

Kaplan, R.S. 1986, 'The Role for Empirical Research in Management Accounting', Accounting, Organizations and Society, 11, 4/5: 429-452.

Kennerley, M., Neely, A. and Adams, C. 2003, 'Survival of the fittest: measuring performance in a changing business environment.' Measuring Business Excellence, 7, 4: 3743.

Kirshnamoorthy, G. 2002, 'A Multistage Approach to External Auditors' Evaluation of the Internal Audit Function', Auditing: A Journal of Practice and Theory, 21, 1: 95-121.

Lapsley, I., Miller, P. and Panozzo, F. 2010, 'Accounting for the City', Accounting, Auditing and Accountability, 23, 3: 305-324.

Lempe, J. C. and Sutton, S. G. 1994, 'Evaluating the work of internal audit: A comparison of standards and empirical evidence', Accounting and Business Research, 24, 96: 335-348.

Leithhead, B. S. 1999, 'Managing change and size risks' Internal Auditor, 56, 6: 68-69.

Leung, P., Cooper, B. and Robertson, P. 2004, Role of Internal Audit in Corporate Governance and Management, RMIT University, Melbourne.

Leung, P., Coram, P. and Cooper, B. J. 2007, Modern Auditing and Assurance Services, 3rd ed., John Wiley and Sons Australia Ltd: Milton, Australia.

Leung, P., Cooper, B.J. and Perera, L. (2011), 'Accountability Structures and Management Relationships of Internal Audit: An Australian Study', Managerial Auditing Journal, 26, 9: 794-816.

Majdalawieh, M. and Alkafaji, Y. (2012), 'Outsourcing the Internal Audit Activities: An Empirical Study of Practices in the United Arab Emirates (UAE)', Internal Auditing, 27, 6: 25-36. 
Martinov-Bennie, N. and Soh, D.S.B. 2009, 'The Relationship Between the Audit Committee and the Internal Audit Function: Evidence from Australia', Working Paper Series, Available at SSRN: http://ssrn.com/abstract=1477852

Mayston, D. 1993, 'Principals, Agents and the Economics of Accountability in the New Public Sector', Accounting Auditing and Accountability Journal, 6, 3: 68-96.

McPhee, I. 2005, 'The relationship of the ANAO with Audit Committees and Internal Audit', Public Sector Audit Network Group, Thursday, 11 August.

Mihret, D.G. and Admassu, M.A. (2011), 'Reliance of External Auditors on Internal Audit Work: A Corporate Governance Perspective', International Business Research, 4, 2: 67-79.

Miller, P. and O’Leary, T. 1998, 'Finding things out', Accounting, Organizations and Society, 23, 7: 709-14.

Morrell, K. 2006, 'Policy as Narrative: New Labour's Reform of the National Health Service', Public Administration, 84, 2: 367-385.

Munro, L and Stewart, J. (2011), 'External Auditors' Reliance on Internal Auditing: Further Evidence', Managerial Auditing Journal, 26, 6: 464-481.

Prawitt, D., Sharp, N.Y. and Wood, D.A. (2011), 'Reconciling Archival and Experimental Research: Does Internal Audit Contribution Affect the External Audit Fee?', Behavioural Research in Accounting, 23, 2: 187-206.

Qian, W., Burritt, R. and Munroe, G. 2011, 'Environmental Management Accounting in Local Government', Accounting, Auditing and Accountability Journal, 24, 1: 93-128.

Rainey, H. 1997. Understanding and managing public organizations, San Francisco: JosseyBass.

Redmayne, N., Bradbury, M. and Cahan, S. 2010, 'The effect of political visibility on audit effort and audit pricing', Accounting and Finance, 50: 921-939.

Raghunandan, K., Read, W. J. and Rama, D. V. 2001, 'Audit committee composition, 'gray directors' and interaction with internal auditing', Accounting Horizons, 15, 2: 105-118.

Sarens, G., De Beelde, I. and Everaert, P. 2009, 'Internal Audit: A Comfort Provider to the Audit Committee', The British Accounting Review, 41, 2: 90-106.

Schneider, A. 1985, 'The Reliance of External Auditors on the Internal Audit Function', Journal of Accounting Research, 23, 2: 911-919.

Singleton,G., D. Aitken, B. Jinks and J. Warhurst, 2003, Australian Political Institutions, $7^{\text {th }}$ ed., Pearson Education, Frenchs Forrest.

Stein, M. T., Simunic, D. A. and O'Keefe, T. B. 1994, 'Industry differences in the production of audit services', Auditing: A Journal of Practice and Theory, 13 (Supplement): 128-142. 
Stewart, J. and Subramaniam, N. (2010), 'Internal audit independence and objectivity: emerging research opportunities', 25, 4: 328-360.

Walker, P. L., Shenkir, W. G. and Barton, T. L. 2003, 'ERM in practice', The Internal Auditor, 60, 4: 51-55.

Ward, D. and Robertson, J. 1980, 'Reliance on Internal Auditors', Journal of Accountancy, October: 62-73.

Watts, R. and Zimmerman. J. L. 1986, Positive Accounting Theory, Prentice-Hall Inc., Englewood Cliffs, N.J.

Whittington, R. 1989, 'New Study on Using Internal Auditors' Work', Journal of Accountancy, May: 123-127.

Yin, R.K.1994, Case Study Research: Design and Methods, 2nd edn, SAGE: Thousand Oaks.

Zammit, S. and Baldacchino, P. 2012, 'Overcoming Barriers between the Internal and External Audit Functions in Malta', International Journal of Government Auditing, April. 


\section{APPENDIX 1 \\ Public Sector Audit Quality Project \\ ABC Police \\ Participant Pre-Questionnaire: Internal Auditor(s)}

Name:

Phone:

Please provide a response to the questions below. If you do not have sufficient space to provide your answers please feel free to use additional note paper and append to this sheet.

1. What is your position title?

2. What is your highest level of education and in which discipline (eg Degree, Diploma, Post-grad)?

3. What year was your qualification achieved?

4. What professional accreditation(s) do you possess? (eg. CIA, CPA, CA, FAICD)

5. Number of PD hours completed (on average) annually

6. What PD topics did you participant in over the past 12 months (eg audit, IFRS, governance, risk)?

7. Where were these events held (eg Perth, interstate)?

8. How many years have you worked as an internal auditor?

9. Has your experience been in the public sector only or public yrs) and private sector ( yrs)

10. How many years have you served with ABC Police?

If you have used a separate sheet(s) of paper to answer any of the above questions, please staple to this sheet and write below the number of sheets including this one.

Number of sheets returned 


\section{APPENDIX II}

\section{Public Sector Audit Quality Project \\ ABC Police Interview Guide \\ Internal Auditor(s)}

1. To whom are you immediately accountable?

2. Who is your director?

3. Who is the audit team leader?

4. Who reports to you?

5. What are the main objectives of Internal Audit within your organisation? Please rank these in order of importance.

6. Do you have an Internal Audit strategy/charter agreed by the Audit Committee?

7. How many years forward does the Internal Audit Strategy/Charter project?

8. Briefly outline the quality control system utilised within the internal audit department.

9. Do you believe the QA system is effective and reliable? Can you recount an instance where it was useful in your work?

10. Do you ever seek independent advice from outside the organisation on an issue?

11. Do you have a compliance framework in place?

12. Is any of the internal audit work outsourced? If so, what percentage? What specific type of work is outsourced?

13. With state government agencies being asked to reduce their spending by $3 \%$ has this had an impact on your department?

14. If you answered 'yes' to Q13, explain how.

15. With more emphasis on risk management within the organisation, how has this impacted on your department in terms of work hours / duties / staffing?

16. Does your organisation train and develop existing staff or recruit experienced staff from outside the organisation?

17. What is your relationship with the audit committee?

18. Do you have easy access to the chair of the audit committee if necessary?

19. How often do you meet with the external auditor (OAG or its representative firm)? Who is your Director? Audit Team Leader? 
20. How much do you perceive the OAG relies upon the internal audit work (eg 100\%; $60 \%$ etc)? In other words, what value is placed on internal audit reports by the OAG.

21. With respect to your interaction with external auditors do you coordinate your work with respect to areas of audit coverage; work schedule?

22. Do the external auditors have free access to all of your work papers; reports?

23. What is your perception on the nature and extent of the external auditor's reliance on internal audit work?

24. How much do you perceive management rely upon the work you prepare for them (eg $100 \%, 60 \%$ etc)? In other words, what value is placed on internal audit reports by management.

25. Have you discovered any frauds in the last three years (this will obviously need to be in general - privacy)?

26. If you answered 'yes' for Q25 how was this risk managed so there was less chance of a recurrence?

27. To what extent are internal audit services requested within the organisation?

28. When reporting your major findings, do you include an executive summary?

29. When reporting your major findings, do you present these to the executive?

30. Are management comments incorporated into your final report?

31. Do you report all findings to the audit committee?

32. Do you have any other comments? 


\section{APPENDIX III \\ Public Sector Audit Quality Project External Auditor Interview Guide}

Q: What are the main audit objectives of external audit in relation to the ABC Police audit? Please rank these in order of importance.

Q: What is your role in the audit planning of the ABC Police audit?

Q: What proportion of the total audit hours is devoted to audit planning?

Q: Briefly outline the review processes around the ABC Police audit

Q: Is any of the internal audit work outsourced? If so, what percentage? What specific type of work is outsourced?

Q: With state government agencies being asked to reduce their spending by $3 \%$, what impact has this had on your department?

Q: How does the OAG train and develop existing staff to ensure they are up to date on the latest developments in audit methodology, public sector issues etc from outside the organisation?

Q: To what extent does the OAG recruit externally to fill gaps in experience and technical audit skills? What is the largest source of external recruits?

Q: What is the relationship between the audit team and the audit committee?

Q: How would you describe the accessibility of the chair of the audit committee?

Q: How often do you meet with the internal auditor? With whom does the audit team specifically meet?

Q: How much does the audit team rely upon the internal audit work (e.g. 100\%, 60\% etc) in completing the audit?

Q: If reliance is placed on the work of the internal auditor, please outline what areas of internal audit work would be relied on most often.

Q: Please identify and rank the top 3 factors that are taken into account when deciding whether or not, and to what extent to rely on the work of the internal auditor?

Q: Does the audit team have free access to all of the internal audit work papers; reports?

Q: Have you discovered any frauds in the last 3 years?

Q: When reporting your major findings, please outline the chain of reporting

Q: What is the nature of the findings that get reported to the audit committee? 